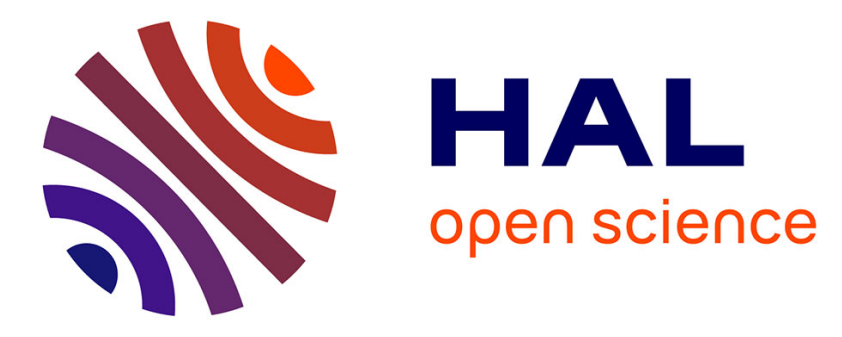

\title{
Development of a wireless Plug\&Lean system for improving manufacturing equipment diagnosis
}

Javier Santos, Martha-Patricia Garcia, Elizabeth Viles, Mikel Arcelus, Jon Uranga

\section{- To cite this version:}

Javier Santos, Martha-Patricia Garcia, Elizabeth Viles, Mikel Arcelus, Jon Uranga. Development of a wireless Plug\&Lean system for improving manufacturing equipment diagnosis. International Journal of Computer Integrated Manufacturing, 2011, 24 (04), pp.338-351. 10.1080/0951192X.2011.554874 . hal-00681223

\section{HAL Id: hal-00681223 \\ https://hal.science/hal-00681223}

Submitted on 21 Mar 2012

HAL is a multi-disciplinary open access archive for the deposit and dissemination of scientific research documents, whether they are published or not. The documents may come from teaching and research institutions in France or abroad, or from public or private research centers.
L'archive ouverte pluridisciplinaire HAL, est destinée au dépôt et à la diffusion de documents scientifiques de niveau recherche, publiés ou non, émanant des établissements d'enseignement et de recherche français ou étrangers, des laboratoires publics ou privés. 


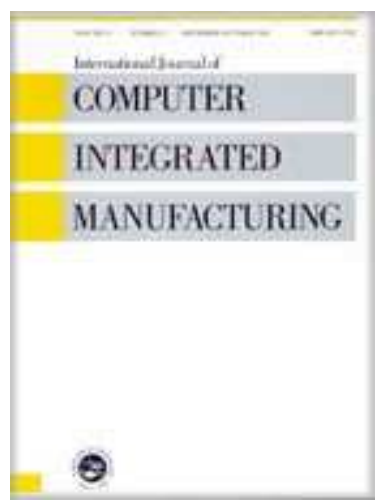

\section{Development of a wireless Plug\&Lean system for improving manufacturing equipment diagnosis}

\begin{tabular}{|r|l|}
\hline Journal: & International Journal of Computer Integrated Manufacturing \\
\hline Manuscript ID: & TCIM-2010-IJCIM-0155.R1 \\
\hline Manuscript Type: & Original Manuscript \\
\hline Author: & 07-Dec-2010 \\
\hline Complete List of Authors: & $\begin{array}{l}\text { Santos, Javier; TECNUN School of Engineers University of Navarra, } \\
\text { Industrial Management } \\
\text { Garcia, Martha-Patricia; TECNUN School of Engineers University of } \\
\text { Navarra, Industrial Management } \\
\text { Viles, Elizabeth; TECNUN School of Engineers University of Navarra, } \\
\text { Industrial Management } \\
\text { Arcelus, Mikel; TECNUN School of Engineers University of Navarra, } \\
\text { Industrial Management } \\
\text { Uranga, Jon; TECNUN School of Engineers University of Navarra, } \\
\text { Industrial Management }\end{array}$ \\
\hline Keywords: & OPERATIONS MANAGEMENT, PRODUCTIVITY IMPROVEMENT \\
\hline Keywords (user): & OEE, RFID, ZigBee, Operation planning and control \\
\hline
\end{tabular}

\section{SCHOLARONE ${ }^{\text {TM }}$ \\ Manuscripts}




\section{Development of a wireless Plug\&Lean system for improving manufacturing equipment diagnosis}

Javier Santos (*), Martha-Patricia García, Mikel Arcelus, Elisabeth Viles, Jon Uranga

TECNUN School of Engineering, University of Navarra, Spain.

Give full correspondence details here

Javier Santos

Email: jsantos@tecnun.es

Industrial Management Department

TECNUN School of Engineering

University of Navarra

Paseo Manuel Lardizabal No. 13

San Sebastian Spain, 20018

Phone: 943219877

(Received 11 November 2009; final version received

Short biographical notes on all contributors

Javier Santos is professor of Operations Management and is Head of the Industrial Management Department at the Engineering School, Tecnun, University of Navarra, Spain. He received his Ph.D. in Industrial Engineering from the University of Navarra. He has been working as industrial consultant and conducted more than 200 graduate master thesis related to Lean manufacturing and Production planning and scheduling, which are his main research interest.

Javier Santos

Email: jsantos@tecnun.es

Industrial Management Department

Engineering School TECNUN

University of Navarra

Paseo Manuel Lardizabal No. 13

San Sebastian Spain, 20018

Phone: 943219877

Martha Patricia Garcia is Professor of Operations Management at Industrial Engineering Department of the Institute Technologic of Chihuahua II, México. She graduated in Master of Science in Industrial Engineering from New Mexico State University. Since February 2009, she is attending a Doctoral Program in the Engineering School, Tecnun, and University of Navarra, Spain. Her research interest is Lean Manufacturing, Supply Chain Management and Logistics.

Martha Patricia Garcia

Email: pgarcia@tecnun.es

Industrial Management Department

Engineering School TECNUN

University of Navarra

Paseo Manuel Lardizabal No. 13

San Sebastian, Spain, 20018

Phone: 943219877 
Elizabeth Viles is professor of Statistics and Design of Experiments at Industrial Management Department, Engineering School, Tecnun, University of Navarra, Spain. She received his Ph.D. in Physics from the University of Navarra and her BS in Mathematics from the University of Zaragoza. She has been working as a lecturer in the same topics and conducted and publishing researches on the use of statistical tools for improving quality and reliability. She is an industrial consultant and regular conference speaker in Quality Management, Six Sigma and acting as a trainer of Black Belt.

Elisabeth Viles Dies

Email: eviles@tecnun.es

Industrial Management Department

Engineering School TECNUN

University of Navarra

Paseo Manuel Lardizabal No. 13

San Sebastian Spain, 20018

Phone 943219877

Mikel Arcelus is professor of Business Administration at Industrial Management Department, Engineering School, Tecnun, University of Navarra, Spain.

$\mathrm{He}$ received his Ph.D. in Industrial Engineering from the University of Navarra. He was working as General Manager and Production Manager during 10 years in different Companies. He also has been working as industrial consultant. He has conducted more than 100 graduate master thesis related to lean manufacturing, improvement processes, reward systems for manufacturing workers and innovation processes which are his main research interests.

Mikel Arcelus Alonso

Email: marcelus@tecnun.es

Industrial Management Department

Engineering School TECNUN

University of Navarra

Paseo Manuel Lardizabal No. 13

San Sebastian Spain, 20018

Phone: 943219877

Jon Uranga is attending a Master program in Industrial Engineering at Engineering School, Tecnun, Universidad de Navarra, Spain. He has been training in Lab VIEW and Lean quality tools. His research interest is the design of software and electronic devices.

Jon Uranga

Industrial Management Department

Engineering School TECNUN

University of Navarra

Paseo Manuel Lardizabal No. 13

San Sebastian Spain, 20018

Tel. 943219877

Phone: 943219877 


\section{Development of a wireless Plug\&Lean system for improving manufacturing equipment diagnosis}

\section{Introduction}

Historically, manufacturers have grappled with ways to improve the productivity of their production process, particularly when it comes to equipment efficiency. The biggest challenge lies in how to measure and get accurate data with less effort, and how to interpret data while carrying out improvements.

Manufacturing companies are aware of the importance of effectively managing equipment efficiency in order to continuously improve the production process. After all, most losses in productivity originate from a lack of proper equipment efficiency management. If equipment efficiency is not measured and controlled, it will be difficult to be competitive in terms of quality, cost and service. Operation Management (OM) provides Lean methodologies to help control this efficiency. Total Productivity Maintenance (TPM) practices measure and control this efficiency by means of the availability rate (the capacity of equipment to be operating when required), the performance rate (the capacity of equipment to keep up with the established working rhythm) and the quality rate (the capacity of equipment to produce the correct product at the first go).

Production measurement demands special attention in order to be competitive; it needs to be supported by a cutting-edge data-collecting technique in order to control and stabilize the processes. This task is further complicated when managers work with inadequate or a lack of technical equipment documentation. Furthermore, some managers fail to recognize data that is useful for making decisions when they already have data based on the previous month's diagnosis.

The use of inadequate techniques to measure equipment efficiency can result in an increase in unplanned failures, which are inherently costly to the organization. These costs include rework, over time cost for late orders, scrap and lost orders due to unsatisfied customers (Moore \& Starr, 2006). It should be noted that these costs could make up anywhere from $15 \%$ to $70 \%$ of the total production cost (Bevilacqua $\&$ Braglia, 2000). As a result, these failures decrease not only a company's productivity but also its profitability. 
A great deal of research has been done in recent years on methodologies for improving productivity (Grunberg, 2004; Kapplan \& Norton, 2005; Anderson et al., 2010; Tangen, 2005). However, little research has focused on accurate measuring and efficient data-collection as the primary step towards determining losses in productivity that stem from production equipment (Huang et al., 2002; Muchiri \&Pintelon, 2008). As a consequence, how and where to measure are questions that all companies need to consider. Companies also need to understand that it is necessary to change their current manual data collection practices for two particular reasons: First, a large amount of significant and trivial multivariate data can be collected and can pile up without time for analysis. Second, the automation of the production process results in a complicated displays of rates (Gourgand et al., 2003)

Information and communications technology (ICT) has a key role to play in driving innovation and competitiveness for the manufacturing and service sectors. There have been many dramatic changes in electronics, computing and telecommunications, which means this new technological revolution is changing the way companies work. The introduction of these new technologies in the industrial sector requires new strategies and management methodologies (Chuang et al., 2009). For example, there is a variety of sophisticated electronic equipment available that provides real-time graphical monitoring of manufacturing data, supported by a set of computerized technologies that display large amounts of data. In addition quality techniques for continuous improvement are evolving (TQM, QFD, and TOC); however, there is no structured procedure for introduce them into the continuous improvement process (Hipkin \& De Cock, 2000). Furthermore, with regard to operators, the implementation of quality tools to improve shop floor management is very slow due to complex manufacturing systems (Hernandez, 2006).

A few companies, especially large ones, are adopting these technologies and sophisticated electronic equipment. Most of them have wired systems for gathering multiple streams of data from multiple points in the company, and the information is processed by more than one software application. In addition, they display a large amount of information on monitors at multiple points in the company (Ho, \& Lin, 2004). At the same time, there are few pilot projects based on mobile and wireless devices in the field of TPM because academia has paid little attention to this particular combination (Thun, 2008). 
This paper does not attempt to introduce TPM as a maintenance practice, or to replace current high-tech manufacturing solution systems. Instead, this research project focuses on how to make the tasks of measuring and data collection easier and more easily understood, resulting in clear, graphical information about the performance of production equipment in order to apply improvements to the right area and in a timely manner through a wireless continuous improvement tool.

Taking into account the common measuring practices previously mentioned, the aim of this paper is to propose a system called "Plug\&Lean." This system is supported by a Plug\&Lean device, which is composed of cutting-edge mobile and wireless devices. The system provides an easy and flexible way to collect data from equipment (Plug) in order to diagnose performance, display graphical reports that focus on the main constraints present in the equipment, and direct alternative improvement activities by means of continuous improvement tools (Lean methodology). As a result, the use of the device confirms new levels of productivity operations once it is restarted. To illustrate the applicability and advantages of this research, results from two case studies in small business will be described.

After reviewing the state of the art, we made chart comparing the current manufacturing solution systems Figure 1(a) and the Plug\&Lean system Figure 1(b). We expect the results of this research to lead not only to a new system but also to a new practice that will have the potential to shift measurement practices in manufacturing companies towards determining and eliminating productivity losses with support from wireless technology. We believe that our research will be greatly benefit small businesses, worker training programs and academia.

\section{Literature review}

Three theoretical concepts are relevant to our research. The first concept is Operation Management (OM) which has won worldwide recognition from manufacturers due to three reasons: (1) it solves current issues facing executives; (2) it gathers major breakthrough manufacturing-philosophy tools known as Lean Manufacturing, pioneered by the Japanese Toyota Production System (TPS); and (3) it is constantly developing new processes based on technology. The Plug\&Lean system has a place in the field of OM because it solves the challenging problem of how to improve efficiency and it is supported by both a cutting-edge philosophy, i.e. TPM, and by mobile and wireless technology. 
The second concept is Total Productive Maintenance (TPM) whose main goal is to maximize equipment effectiveness. According to Nakajima (1988), the overall equipment effectiveness (OEE) measurement is an effective way to analyze the effectiveness of a single machine or an integrated manufacturing system. .Nakajima (1988) focused on three basic indicators: availability, performance and quality. Moreover, these three dimensions are measures of equipment losses, which Nakajima classified these losses into six major categories (Figure 2).Figure 2 also shows an illustration of an OEE equations and calculation for a single piece of equipment, and shows how these six main losses reduce real operation time.

The third relevant theoretical concept is wireless technology which has become a key media for communications. As a result, there has been an increase in different wireless technologies, which are spreading and constantly being innovated (e.g., radio frequency identification-RFID, ZigBee, Bluetooth) (Huang et al., 2008(a)). Since these technologies are supported by multiple wireless capabilities and ubiquitous services, they are used in almost all fields (Kuorilehto et al., 2007). In addition, wireless technologies are known for the small size of their components, low cost, high speed data transfer and effortless installation. These technologies are leading the way in the development of miniature devices and replacing microcontrollers and traditional sensors with smart sensors (Flammini et al., 2008). Wireless means that the devices are equipped with certain technologies that enable them to connect to other wireless devices and support for mobility. The purpose of these wireless connections is to share information between devices, without worrying about cables and physical interface tools.

Wireless local area networks (WLAN) and wireless personal area networks (WPAN) are the protocols best suited for industrial applications and have come to monopolize the wireless market (Kuorilehto et al., 2007). The industrial requirements identified in order to utilize wireless technology are: interoperability, accessibility, scalability, flexibility, high availability, immunity to interference and security; additional required features are portability, low power consumption and low cost. In this context the two WPAN applications most qualified to be incorporated in our research are RFID and ZigBee, whose main features are presented in Figure 3.

The use of RFID has recently become an undeniable and unstoppable trend in a number of applications, including supply chain management, public transportation, livestock tracking, security, access control, inventory management and many others 
(Brusey and Mc Farlane, 2009). RFID technologies are starting to be used to achieve real-time collection of work flow data and create real-time visibility and traceability throughout the entire enterprise (Huang et al., 2007; Zhang et al., 2010). However, RFID does not exist in the form of a readily available solution for the manufacturing scenario (Huang et al., 2008(a)).The main competitor to RFID tags is ZigBee. ZigBee has been readily accepted by industry thanks to its high reliability and high level of interoperability and attributes such as its ability to support many more nodes per network, work under lower latency, perform well in low SNR (signal noise radio) environments, and link to networks on a faster basis. ZigBee is most commonly utilized in controlling and monitoring applications and its most important value is low power consumption (the battery can sleep for minutes or even hours) (Pan \& Tsen, 2008).

\subsection{Related work}

This section reviews previous work related to the introduction of wireless communications technologies in manufacturing systems in order to measure the performance of production equipment through the current issue of "real-time monitoring". The studies we selected to review came from searching the literature using the keywords monitoring, data collection, improve equipment efficiency, and wireless devices.

In recent years a significant number of research studies, European projects, and industrial developments regarding the monitoring of manufacturing performance and the improvement of equipment efficiency has resulted in proposals such as ubiquitous systems (Jeong et al., 2009), real-time wireless manufacturing management (Huang et al., 2008(b)), and devices and web solutions for the areas of maintenance and condition based monitoring (CBM). However, very few have been in the TPM area.

In reviewing the related research studies, numerous authors (Cao et al. (2009); Campos (2009); Egea-Lopez et al. (2005); Emmanouilidis et al. (2008); Flammini et al. (2008); Han\&Yan (2006); Hernandez-Matias et al. (2008); Ho et al. (2004); Huang et al. (2008 (a)); Jantunen et al. (2009); Jeong et al. (2009); Jun et al. (2009); Kumar (2006); Leung et al. (2006); Levrat et al. (2008); Muller et al. (2008); Thun (2008)) have presented studies that investigate the monitoring of manufacturing performance using wireless communication technologies and the impact on 
maintenance; however, they do not consider portable and wireless devices for collecting data in order to calculate the OEE.

Looking at European projects such as SOA4D, Proteus, Predict, Sirena, and Dynamite, propose software applications, platforms and technologies for supporting real-time condition based monitoring maintenance. Consequently, they provide technological infrastructure for automated OEE calculations but no specific methodology for the improvement of the equipment performance.

Similarly, in reviewing the related developments from industry we found many R\&D companies around the world (e.g. SEMATECH Inc.; Rockwell Automation Inc.; Siemens; National Instruments Corporation and TPM-pro Company) who are making their best contributions to developing technology and building intelligent systems for supporting the real-time monitoring of manufacturing plants. Although these systems suggest complete monitoring performance, in the OEE context there is no specific contribution for a portable and wireless tool for collecting data.

\section{Design considerations for the Plug\&Lean system}

This section reports on our research into designing the Plug\&Lean system. This study takes advantages of the latest developments that facilitate the gathering of data and provide a new tool by utilizing the attributes and the potential of wireless technology, in order to calculate and analyze the OEE. In the same context, this system proposes an understanding of the continuous improvement process for linking diagnosis with actions for improvement in a more "lean" scenario, which can help managers and operators avoid wasting time and effort, according to the next generation of manufacturing systems (NGMS) (Huang et al., 2008(a)). The design system is described in three parts: system design, infrastructure, and implementation.

\subsection{System design}

Formatted: Font color: Formatted: Font color: Red

Formatted: Font color: Red

The system encompasses three main stages in a systematic way (Figure 4). First, the diagnosis stage, aided by the wireless device, collects data and transforms it into information. Second, the focusing stage presents the current levels of equipment efficiency (OEE) by displaying graphical reports and information in order to facilitate their analysis and to focus on the main constraints. Finally, the confirmation stage is where operators and managers can construct a guide containing countermeasures or improvement activities as a plan, do, check, act (Deming's PDCA quality plan). 


\subsection{Infrastructure}

The Plug\&Lean system consists of a Plug\&Lean device (technical infrastructure) and the application management system. The schema of the Plug\&Lean system is shown in Figure 5. The Plug\&Lean device (technical infrastructure) has a novel design featuring a portable and compact set of efficiently assembled small wireless devices that work together seamlessly based on TPM-Lean methodologies. It design allows the device to be easily plugged into a designated area or single piece of equipment in order to read performance during a selected production period. The infrastructure is made up of three elements: (1) a group of wireless devices consisting of collectors and a controller, (2) a system barcode scanner, (3) and a laptop that acts as a PDA. Since the project is based on the Lean philosophy and includes a Lean design, all the elements fit into a portable case.

The application management system manages the information and runs the continuous improvement process program for generating the interface for users and reader-friendly reports. This part of the system acts as the "brain" of the application, where the application management processes and turns the data into knowledge. In addition, this management system takes the knowledge and displays it in a way that makes it easy for operators and managers to take improvement actions. Because the operation has to be user-friendly we decided to include commands based on LabVIEW and Microsoft office platforms. The Microsoft platform was chosen for the reason that practical applications such as Microsoft Access and Microsoft Excel fit perfectly with this research project. The software program that runs the continuous improvement process based on the Lean philosophy is currently under development. This software aims to offer an easily understood guide for operators and personnel in order to identify misaligned tasks, as a root cause analysis (RCA), and to select the most appropriate improvement actions, all in a timely manner.

In order to ensure success in the design and to meet our goals for the system under study, it is relevant to formulate the product design specifications, and to select the components and devices currently available on the market. The specifications of the Plug\&Lean wireless device, which has to be suitable for working in industrial areas, are: to be able to resist noise, humidity, and variable temperatures as well as oily and dusty environments, and longer range without degradation of quality. Additionally, it has to have repeatability high resolution in order to detect the smallest 
changes in signals, and accuracy to measure the exact variation in quantity and low power consumption.

We researched the most appropriate technology on the market to build the Plug\&Lean device and we selected a. company located in Argentina as a supplier because of the low cost, adaptable features and availability of wireless parts. Table 1 illustrates the list of the wireless devices chosen, Figure 6 shows the specification of the components and Figure7 shows the current prototype.

\subsection{Implementation}

Formatted: Font color:

The implementation of the prototype can be described as an operating procedure

(Figure 8). First, establish a measuring plan, determine the initial parameters and prepare the Plug\&Lean device for work. Open a session in the laptop; plug the sensors into the machine or production line to be measured; collect up operational data, such a number of production products, number of good quality products, raw material use, consumable material used, downtime, cause and frequency of downtime events, and other customized required data. In order to capture the causes of downtime, an operator intervenes and performs a scan to code after identify why the equipment is stopped.

The second step is processing the collected data with the TPMpro software. MS Access is used as a database management, and the software allows communication between MS Access and the Plug\&Lean program. At this stage, the Plug\&Lean program recognizes the data in order to calculate the OEE metrics. As a result, reports and graphs can be displayed and printed. Managers can see the equipment rates for quality, performance and availability and can make a diagnosis of the current state of the process (diagnosis stage). They can observe and focus on the misaligned tasks and then improvement activities can be proposed immediately after the device is disconnected from the machine (focusing stage).

Third, once the rate's behavior over time has been analyzed and the required improvements have been implemented, new data will be collected using the Plug\&Lean device as was done in the diagnosis stage. This new data will show the impact of the improvements on the defined rates (confirmation stage). Finally, the company will decide if it is necessary to carry out a shop floor control project, which will establish a procedure to regularly obtain, at a minimum, the same rates obtained 
with the Plug\&Lean device. Traditional shop floor control systems can be used in this final step.

\section{Case study}

The validation phase of this project aims to demonstrate how it is possible to improve equipment efficiency using the information gathered from a piece of equipment using a wireless sensor-based system, in addition to testing the capability and effectiveness of a prototype.

Important preliminary information was provided from two case studies we carried out. In 2004, a company located in Gipuzkoa (Spain) and which manufactures natural wood coating solutions was selected. The company wanted to offer their employees the information necessary to propose, carry out and improve manufacturing line productivity. The OEE rate calculation was introduced using sensors placed along the semiautomatic line to gather performance data which were collected during 2004. In 2005, the study analyzed the OEE rates, focusing on the misaligned task and provided a Lean methodology for improving. After some improvements, the study continued in 2006 and new data was collected in order to confirm an increase in the level of effectiveness of the production line. In Figure 9, the graph on the left represents the availability rate behavior over time in 2004. The drop to zero during weeks 33 and 34 was due to summer break. The graph on the right side in Figure 9 represents the availability rate as from January to May 2006. The graph clearly shows a major improvement: the variability in availability has been eliminated. In addition, for the performance rate from 2004 to 2006, a similar improvement in behavior was seen (Figure 10). In this particular case study, the quality rate was not considered because the line never produces defective batches. Finally, the OEE rate for 2004 was 53.5\%, and at the end of our study in 2006 it was $74.7 \%$. The OEE analysis made it possible to identify and eliminate the sources of variability and failure. This case study showed the possibility of prioritizing improvement actions according to OEE behavior (Santos et al., 2006). Moreover, it showed that the information provided by our system can help companies improve their effectiveness.

In June 2009, we selected a leading bread producer in the Basque Region for our second case study. The company produces 43 different types of frozen bread, and 
they have five continuous production lines. Line number 4 is one of the key lines because of its high level of automation, and thus it was the one selected for our study. The preliminary results are described below.

Because employee involvement is one of the principles in the Lean manufacturing philosophy, our first task was to put together a carefully selected multidisciplinary team in order to plan the overall testing activities for the implementation of the Plug\&Lean system. Meanwhile, another important task was to analyze the procedure that the company was following at the time to collect data and how it calculated its efficiency or performance state. In analyzing the company's practices prior to our case study, we were able to confirm the statements included in the introduction of this paper, namely that the company relies on both manual data collection and has a large amount of unanalyzed data; Furthermore, they were unsure of their performance indicators because they have neither a defined OEE method nor a proper classification of their downtime causes.

Continuing with the experimental task, in order to test the Plug\&Lean application management system, we undertook three actions. First, we determined the input (data) and collected data during July and August 2009. Second, we processed, calculated and analyzed the OEE rates in order to identify losses. Third, we implemented the Plug\&Lean system as a systematic procedure.

Table 2 shows the data (input) used by the company to calculate their production metrics. The data used prior to the case study had inconsistencies based on non-standard measures; the data used during the case study was clearly defined and standardized in order to set-up the input. Data was collected for 10 weeks, from week 27 to week 36. Our program processed the data and calculated the OEE rate each week. During the collection process, we detected the need to add a new rate, which we called "utilization"; utilization refers to the percentage of time that the line was loading and operating (Figure 11).

Figure 12 shows Plug\&Lean graphics, which indicate the level of each one of the rates and allow inconsistencies in the process to be detected immediately. In this case study, the company could see problems with cycle time, operating time and utilization time. In addition, they could see a supporting weekly report (Figure 13); the left side indicates the OEE rates for the previous week, and the right side gives the cumulative OEE rates for the period. In both cases, arrows highlight whether there has been an increase or decrease in values. After analyzing these OEE rates, the company 
made a proper classification of their losses; an example is given in Table 3. The company then could take the opportunity to translate these losses into economic impact. Additionally, they could prioritize each loss in order to focus on counter measures or improvements.

The final step of the study was to introduce the OEE calculations in all production lines of the plant, and to show the company how to standardize the application of the Plug\&Lean system through the adoption of a framework for structuring a continuous improvement plan (Figure 14).

\section{Conclusions and further work}

Our experiences with the current version of the prototype Plug\&Lean device are quite promising (Figure 6). It was tested in a laboratory prior to its introduction to the company. The device functioned consistently, reliably and accurately during testing. In addition, we confirm that ZigBee's performance is simple and comprehensible when it comes to linking all the devices involved, sensing from long distances and displaying reliable data. Currently, we are improving the developments of the downtime application through the scanner barcode tool and the continuous improvement software.

This system does not attempt to replace the system solutions available on the market; rather, we think that it is a valuable preliminary step in providing businesses, especially small businesses, with a system that makes it easy for operators to understand OEE calculations in order to rapidly devise and implement solutions that increase productivity. In the same way, this research benefits academia by allowing students to understand and put into practice manufacturing concepts likes OEE and continuous improvement. We have designed a Plug\&Lean system as a new management tool and a practical system solution to diagnose, focus on, and improve manufacturing operations.

A major area for future work is integrating an additional application in order to Formatted: Font color: Red determine other manufacturing execution system metrics (MES) and the financial benefits after the system has been implemented. In addition, a large part of this project depends on leading wireless technology. Because there is constant change and innovation in this field, ZigBee and RFID devices are certainly going to be improved, meaning that there is a need to keep researching this topic so such devices can be adapted to work better in industrial applications. 
Acknowledgement

This research project is supported by the Basque Government and the University of Navarra

\section{References}

Anderson, J., Cadavid, J and Backstrom, T. (2010). Spatial design for continuous improvement: The case study of three manufacturing companies. International Journal of Computer Integrated Manufacturing IJCIM, Vol. 23 N0. 8-9, pp791-805.

Allio, M. (2006), Metrics that matter. Seven guidelines for better performance measurement. Journal Handbook of Business Strategy, Vol. 7, pp 225-263.

Bevilacqua, M., Braglia, M., (2000). The analytic hierarchy process applied to maintenance strategy selection, Reliability Engineering and System Safety, Vol. 70, pp. 71-83.

Brusey, J. and McFarlane, D.C. (2009). Effective RFID-based object tracking for manufacturing. International Journal of Computer Integrated Manufacturing IJCIM, Vol 22, No.7, pp. 638-647.

Campos, J., (2009). Development in the application of ICT in condition monitoring and maientenance. Computers in industry No. 60, pp 1-20.

Cao, H., Folan, P., Mascolo, J., and Browne, J. (2009). RFID in product lifecycle management: a case in automotive industry. International Journal of Computer Integrated Manufacturing IJCIM, Vol. 22, No. 7, pp 616-637.

Chaffey, D. (2002). E-Business and ecommerce management strategy implementation and practice, Harlow Prentice-Hall.

Chan F.T.S., Lau H.C.W., Chan H.K., Kong, S. (2005). Implementation of total productive maintenance: A case study, International Journal of Production Economics, Vol. 95, pp. 71-94.

Egea-Lopez, E., Martinez-Sala, A., Vales-Alonso, J., García-Haro, J., MalgosaSanahuja, J., ((2005). Wireless communications deployment in industry: a review of issues, options and technologies. Computers in industry, No. 56, pp 29-53.

Emmanouilidis,C., Liyanage, P., Jantunen, E. (2009). Mobile solutions for engineering asset and maintenance management. Journal of Quality in Maintenance Engineering, Vol.15, No. 1, pp 92-105.

Flammini, A., Ferrari, P., Marioli, D., Sisinni, E.,Taroni, A. (2008). Wired and Wireless sensor networks for industrial applications. Microelectronics Journal, Vol. 40, No.9, IEEE, pp 1322-1336.

Gourgand, M., Lacomme,P. And Traore,M.K. (2003). Design of a monitoring environment for manufacturing systems management and optimization. International Journal of Computer Integrated Manufacturing IJCIM. Vol. 16, No.1, pp 61-80.

Grunberg, T., (2004). Performance Improvement towards a method for finding and prioritizing potential performance improvement areas in manufacturing operations, Int. Journal of Productivity and performance Management, Vol. 53, 2004, pp. 52-71.

Han, T. and Yang, B.S., (2006). Development of an e-maintenance system integrating advanced techniques. Computers in industry, No. 57, pp 569-580.

Hernandez-Matias, J.C., Vizan, A., Perez-Garcia, Rios, J. (2008). An integrating modelling framework to support manufacturing system diagnosis for 
continuous improvement, Robotics and Computer Integrated Manufacturing Vol. 24 pp 187-199.

Hipkin, I.B. and De Cock, C. (2000). TPM and BPR: Lessons for maintenance management, Omega, Vol. 28, pp. 282-308.

Ho, L. T. and Lin, G. C. I. (2004). Critical success factor framework for the implementation of integrated-enterprise systems in the manufacturing environment, International Journal of Production Research, Vol. 42, No. 17, pp 3731-3742.

Huang, G.Q., Zhang, Y.F. and Jiang, P.Y. (2007). RFID-based wireless manufacturing for walking-worker assembly islands with fixed-position layouts. Robotics and Computer-Integrated Manufacturing. Vol. 23, pp 469477.

Huang, G.Q., Wright, P.K., Newman, S.T. (2008 (a)). Wireless manufacturing: a literature review, recent developments, and case studies, International Journal of Computer Integrated Manufacturing, Vol. 22, No.7, pp 1-16.

Huang, G.Q., Zhang, Y.F. and Jiang, P.Y. (2008 (b)). RFID-based wireless manufacturing for real-time management of job shop WIP inventories International Journal of Advanced Manufacturing Technology, Vol. 36, pp 752-764.

Huang,S., Dismukes,J., Shi,J., Su,Q., Wang,G., Razzak,M., Robinson,D. (2002). Manufacturing system modelling for productivity improvement, Journal of Manufacturing Systems, Vol. 21, No.4, pp 249-259.

Jantunen, E., Gilabert, E., Emmanoulidis, C., Adgar, A. (2009). E-maintenance, a means to high overall efficiency. Proceedings 4th WCEAM.

Jeong, S., Min-Hur, S., Suh, S.H. (2009). A conceptual framework for computer-aided ubiquitous system engineering: architecture and prototype, International Journal of Computer Integrated Manufacturing Vol. 22, No.7, pp 671-685.

Jun, H.B., Shin, J.H., Kim, Y.S., Kiritsis, D., Xirouchakis, P. (2009). A framework for RFID applications in product lifecycle management. International Journal of Computer Integrated Manufacturing, Vol. 22, No. 7, 2009.

Kaplan, R., and Norton, D. (2005). The Balanced Score Card: Measures that drive Performance, Harvard Business Review.

Kumar, U., (2006). Development and implementation of maintenance performance measurement system: Issues and challenges. Proceeding of the 1st. WCEAM.

Kim,H., Chung,J.,Kim, Ch. (2009). Secured communication protocol for internetworking ZigBee cluster networks. Computers Communications, Vol. 32, (13-14), pp 1531-1540.

Kuorilehto, M., Kohvakka, M., Suhonen, J., P. Hamalainen, P., Hannikainen, M., Hamalainen, T. D. (2007). Ultra low Energy Wireless Sensor Networks Practice: Theory, Realization and Deployment, Wiley.

Leung, T., Lee, K.W., Chung, W.W. (2006). Systems and application development for portable maintenance aid (PMA)-a performance perspective. Journal of Manufacturing Technology Management. Vol. 17, No. 6, pp 786-805.

Levrat, E., Iung, B., Crespo-Marquez, A. (2008). E-maintenance: review and conceptual framework. Production Planning and Control. Vol. 19, No. 4, pp 408-429.

Moore, W.J., and Starr, A.G. (2006). An intelligent maintenance system for continuous cost- based prioritization of maintenance activities, Computers in Industry, Vol. 17 No., pp.595-606. 
Muchiri, P., and Pintelon, L. (2008). Performance measurement using overall equipment effectiveness (OEE): literature review and practical application discussion. International Journal of Production Research, 46(13), 3517-3535.

Muller, A., Crespo-Marquez, A., Iung, B. (2008). On the concept of e-maintenance: Review and current research, Reliab.Eng.Syst.Saf. Vol. 93, No. 8, pp.11651187.

Nakajima, S. (1988). Introduction to TPM, Productivity Press, Cambridge, MA.

Pan,M. and Tsen, Y. (2008). Quick convergecast in ZigBee beacon-enabled treebased wireless sensor networks, Computer communications, Vol. 31 No.5, pp 999-1011

Santos, J., Wysk, R.A. and Torres, J.M. (2006). Improving Production with Lean Thinking, John Wiley\&Sons, Hoboken, NY.

Sharma, R. K., Kumar, D., and Kumar, P. (2006). Manufacturing excellence through TPM implementation: a practical analysis, Industrial Management \& Data Systems, Vol. 106, No.2, pp. 256-280.

Tangen, S. (2005). Demystifying productivity and performance, Int. Journal of Productivity and Performance Management, vol. 54, No.1, pp.34-46.

Thun, J.-H. (2008). Supporting total productive maintenance by mobile devices, Production Planning and Control: The Management of Operations, Vol. 19, No.4, pp. 430-434.

Yin, R. (1994), Case Study Research Methods, Sage Publishing, Newbury Park, CA.

Zhang, YF, Huang,G.Q., Qu,T. and Ho, O. (2010) Agent-based workflow management for $R F I D$-enabled real-time reconfigurable manufacturing.

Formatted: Font color: International Journal of Computer Integrated Manufacturing, Vol.23, No.2, pp 101-112.

Figure 1 Comparison of current system solutions and the Plug\&Lean system Current System Solutions (left) Plug\&Lean System(right)

Figure 2 Nakajima's losses and the OEE calculation (Santos et al., 2006)

Figure 3 Comparison between RFID and ZigBee

Figure 4 The Plug\&Lean system

Figure 5 Plug\&Lean system infrastructure

Figure 6 Specification of components of the Plug\&Lean device

Figure 7 Plug\&Lean device prototype

Figure 8 The Plug\& Lean system procedure

Figure 9 Availability rate improvements from 2004 to 2006

Figure 10 Performance rate improvements from 2004 to 2006

Figure 11 The OEE and the Utilization calculation rates

Figure 12 Case study graphical data

Figure 13 Case study OEE report

Figure 14 Plug\&Lean framework for continuous improvement

Table 1. List of wireless components of the Plug\&Lean device

Table 2. Input data from line 4

Table 3. Time production losses after the Plug\&Lean system 


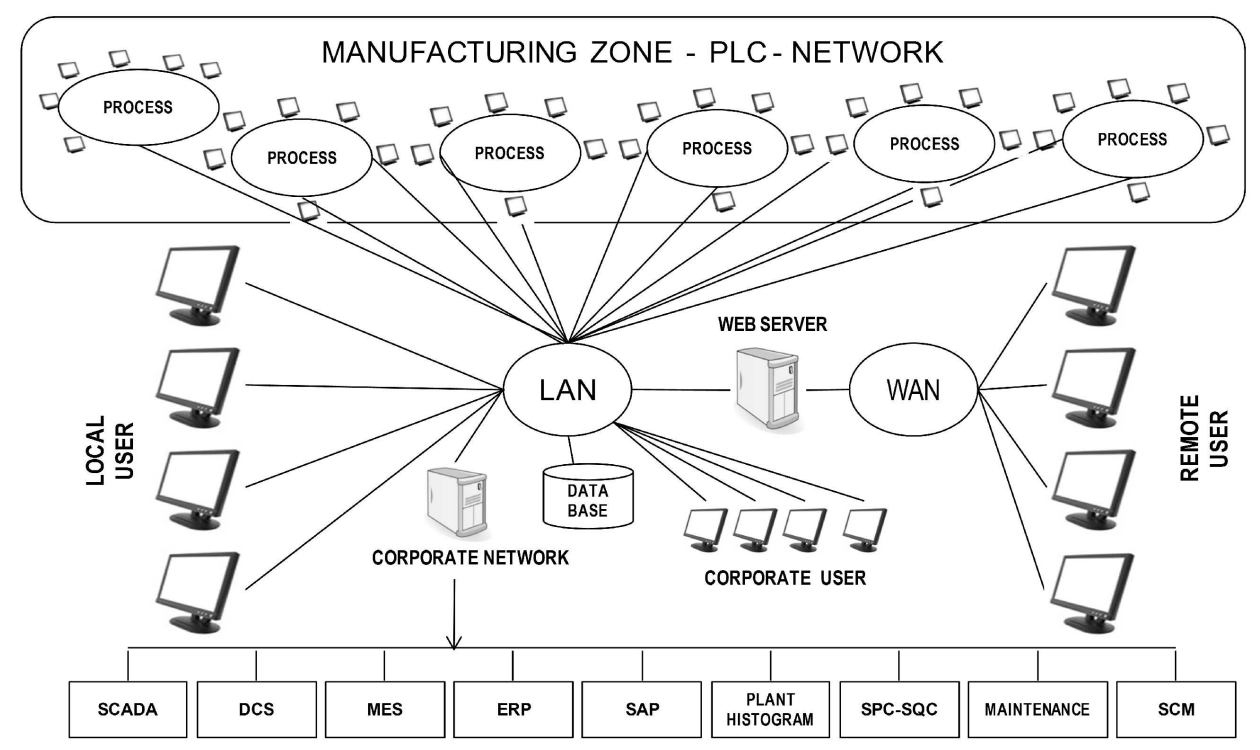

Figure 1a. Comparison of current system solutions and the Plug\&Lean system Current System Solutions (left) Plug\&Lean System(right) $116 \times 71 \mathrm{~mm}(600 \times 600 \mathrm{DPI})$ 


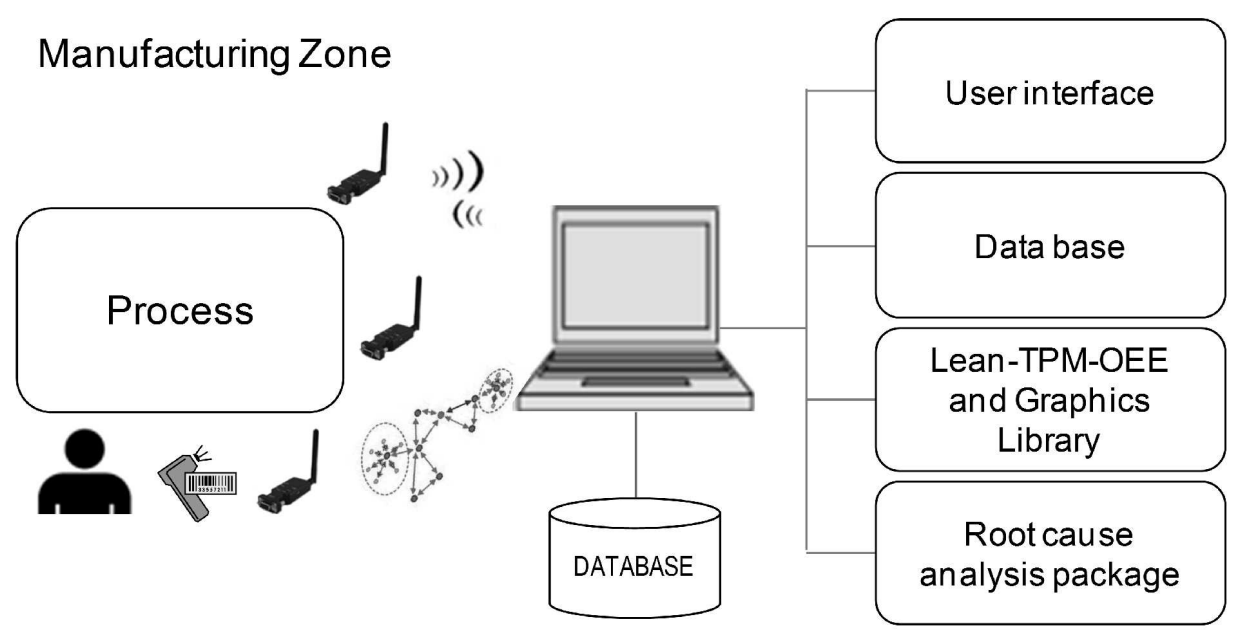

Figure 1a. Comparison of current system solutions and the Plug\&Lean system Current System Solutions (left) Plug\&Lean System(right)

$85 \times 71 \mathrm{~mm}(600 \times 600 \mathrm{DPI})$ 


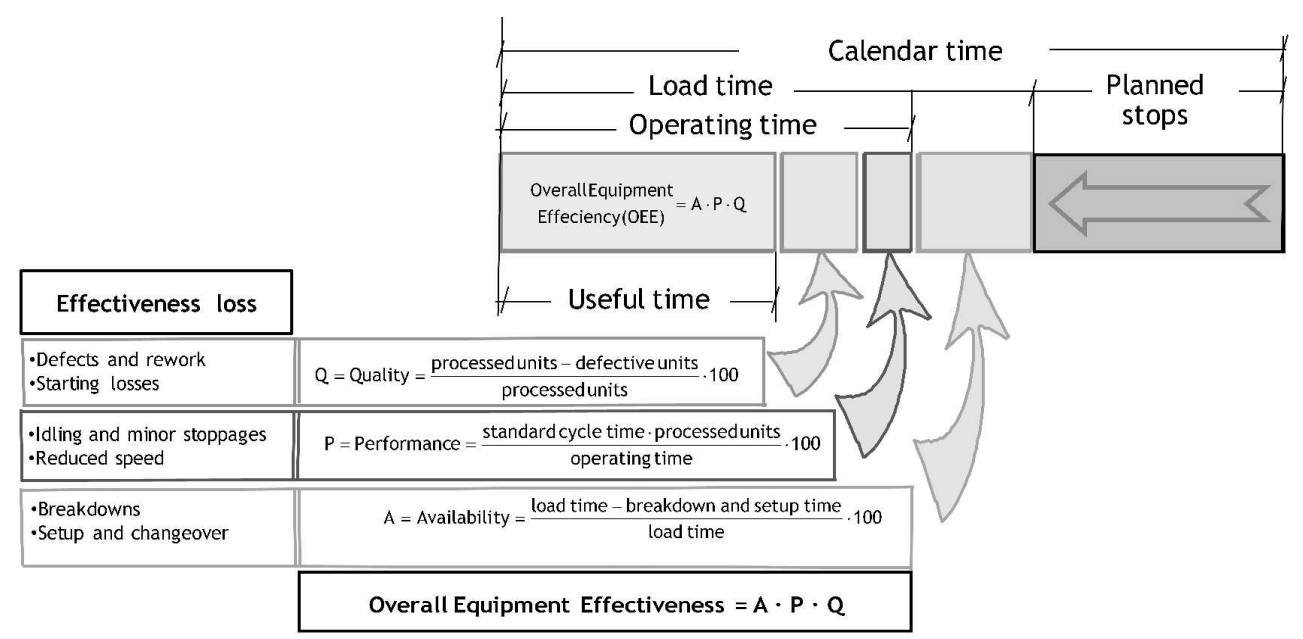

Figure 2. Nakajima's losses and the OEE calculation (Santos et al., 2006) $220 \times 109 \mathrm{~mm}(600 \times 600 \mathrm{DPI})$ 


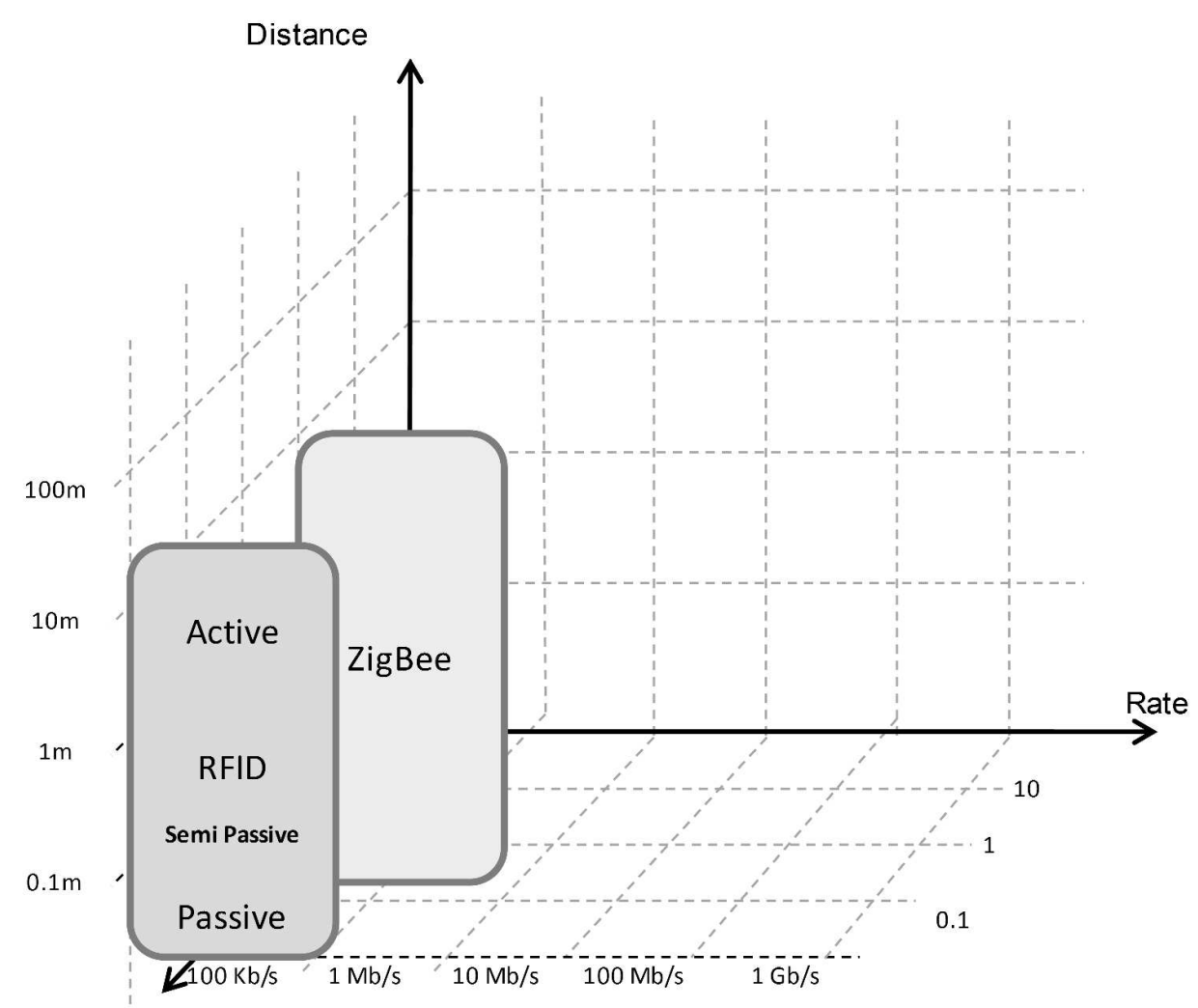

Cost

Figure 3. Comparison between RFID and ZigBee $134 \times 116 \mathrm{~mm}(600 \times 600 \mathrm{DPI})$ 


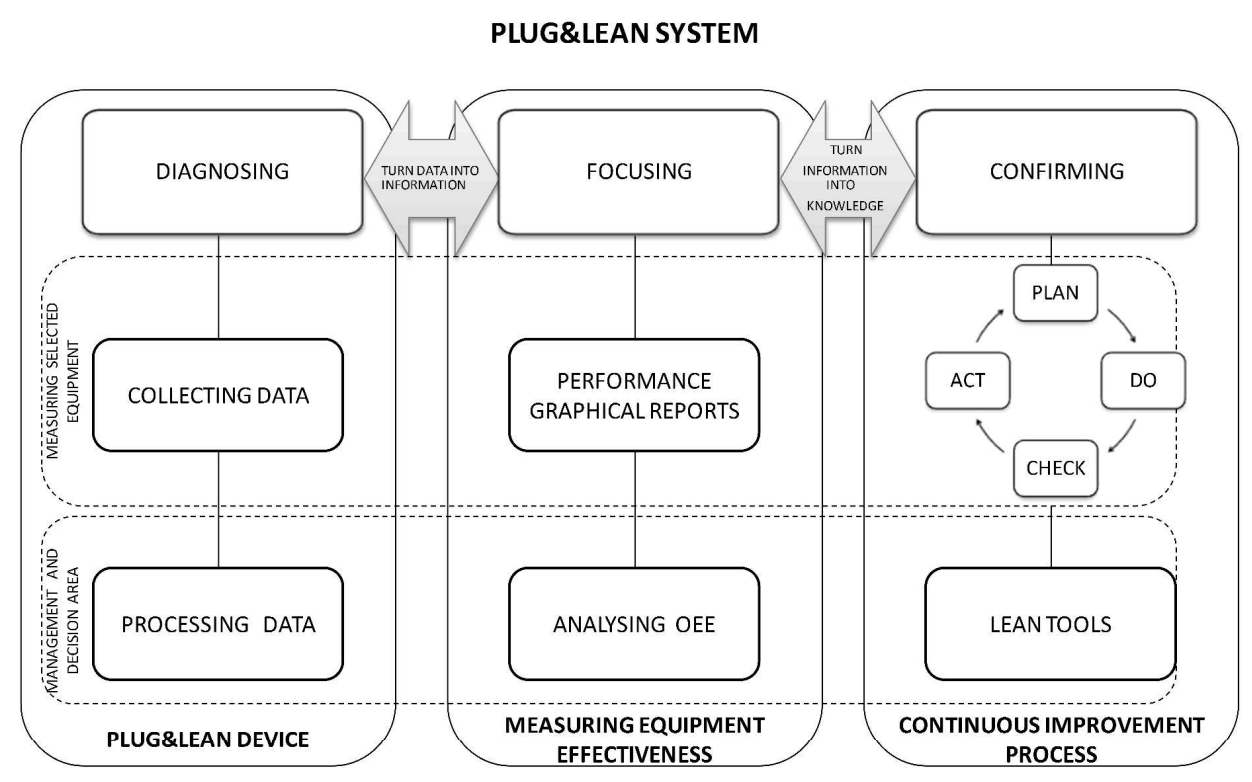

Figure 4. The Plug\&Lean system $250 \times 149 \mathrm{~mm}(600 \times 600 \mathrm{DPI})$ 


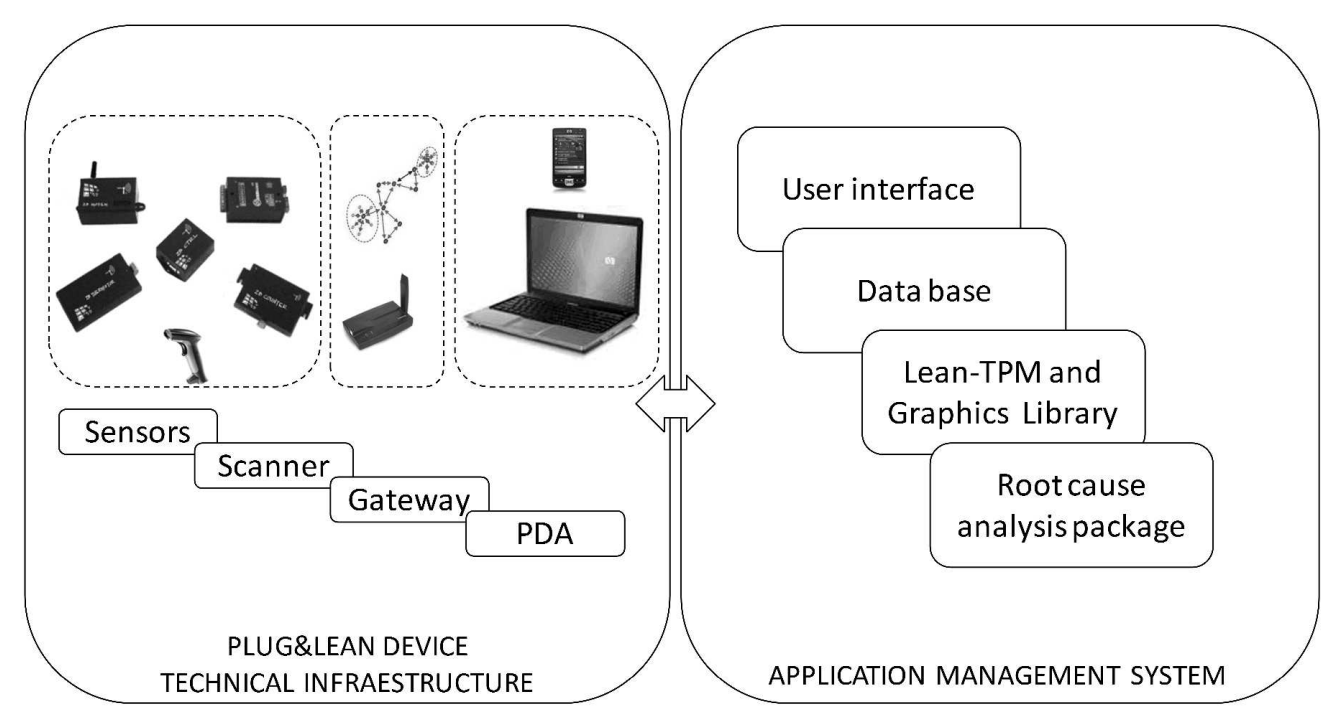

Figure 5. Plug\&Lean system infrastructure $229 \times 125 \mathrm{~mm}(600 \times 600 \mathrm{DPI})$ 


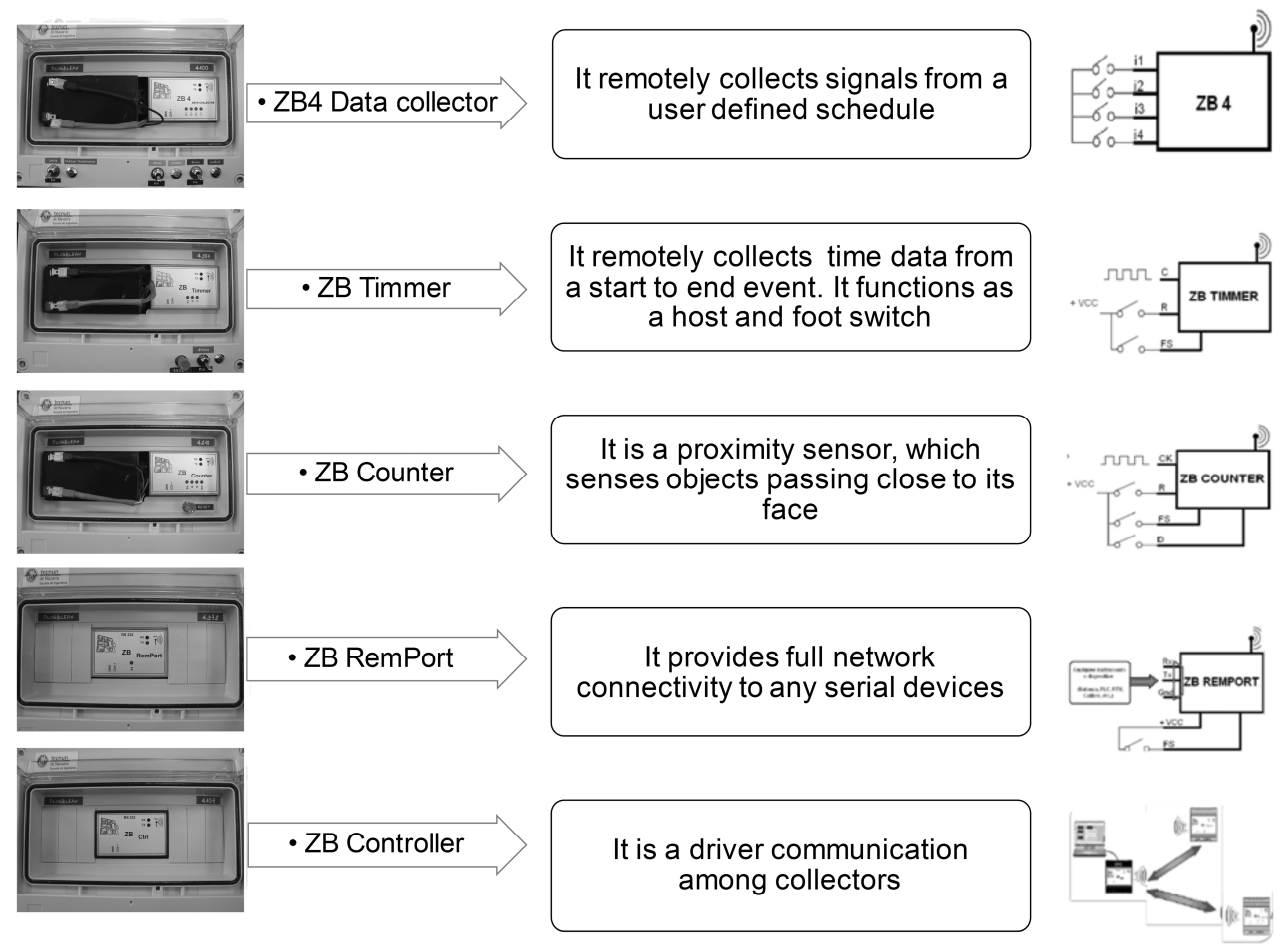

Figure 6. Specification of components of the Plug\&Lean device $199 \times 146 \mathrm{~mm}(600 \times 600 \mathrm{DPI})$ 


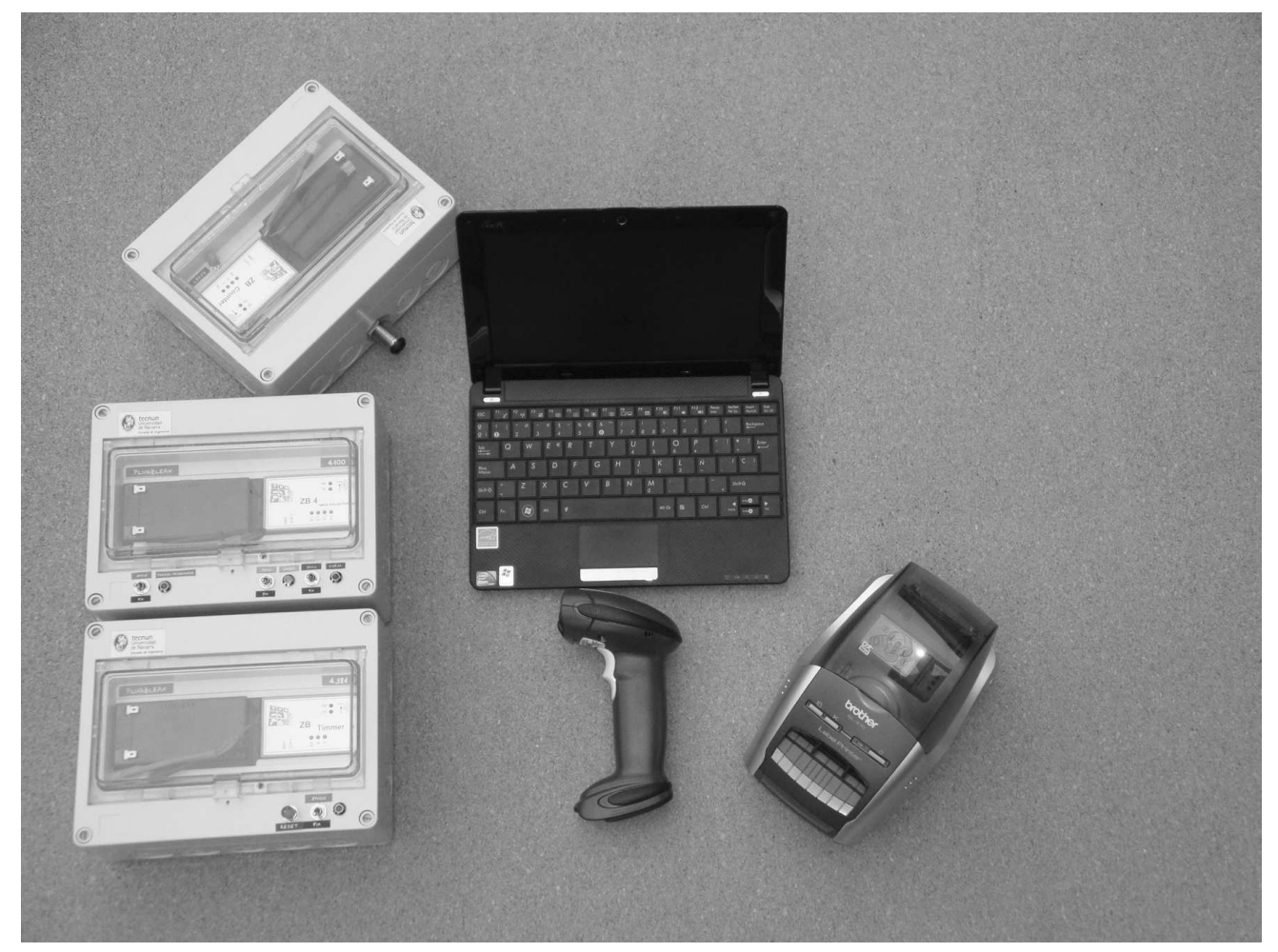

Figure 7. Plug\&Lean device prototype $150 \times 112 \mathrm{~mm}(300 \times 300$ DPI $)$ 


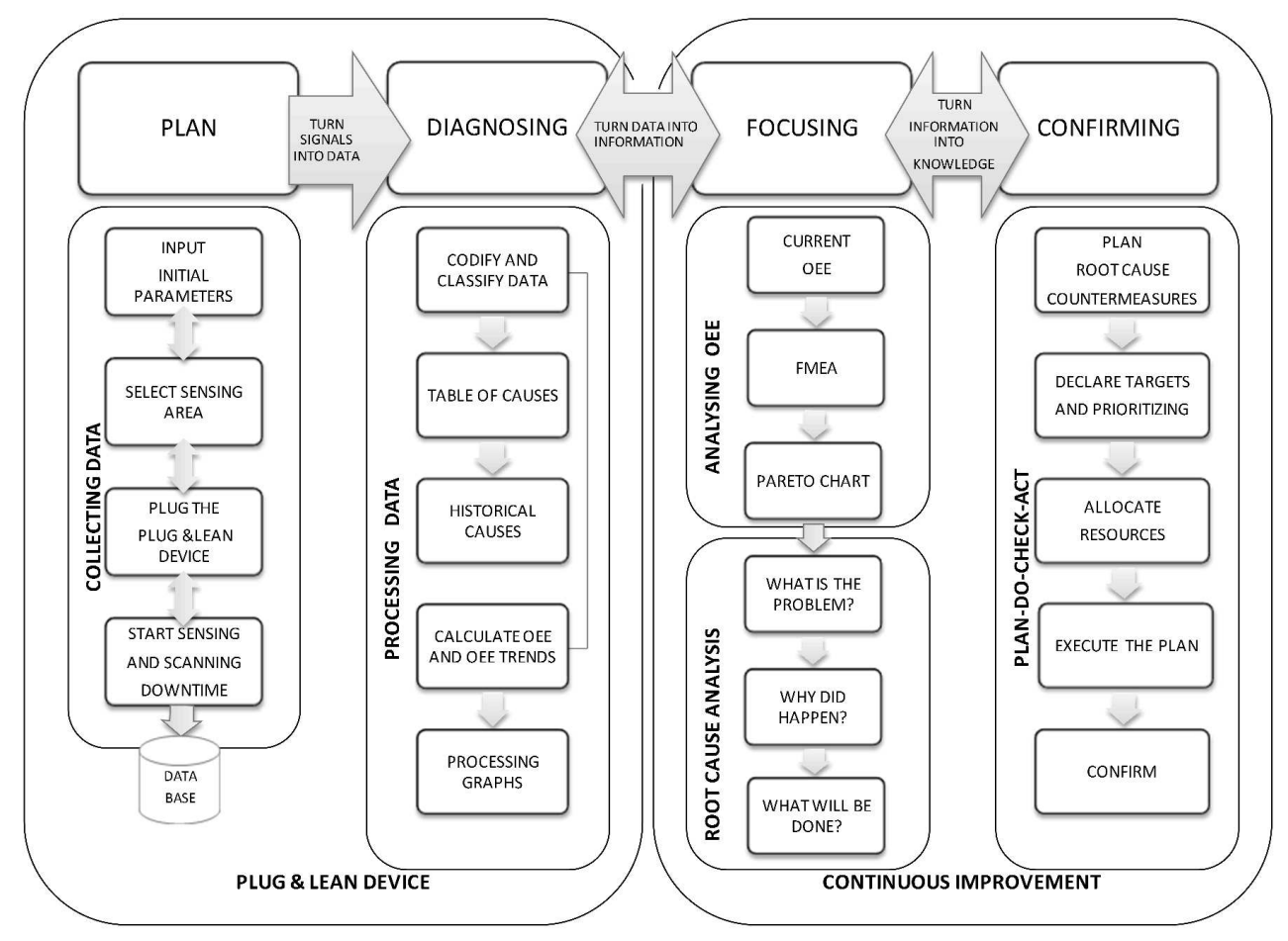

Figure 8 . The Plug\& Lean system procedure $233 \times 169 \mathrm{~mm}(600 \times 600 \mathrm{DPI})$ 

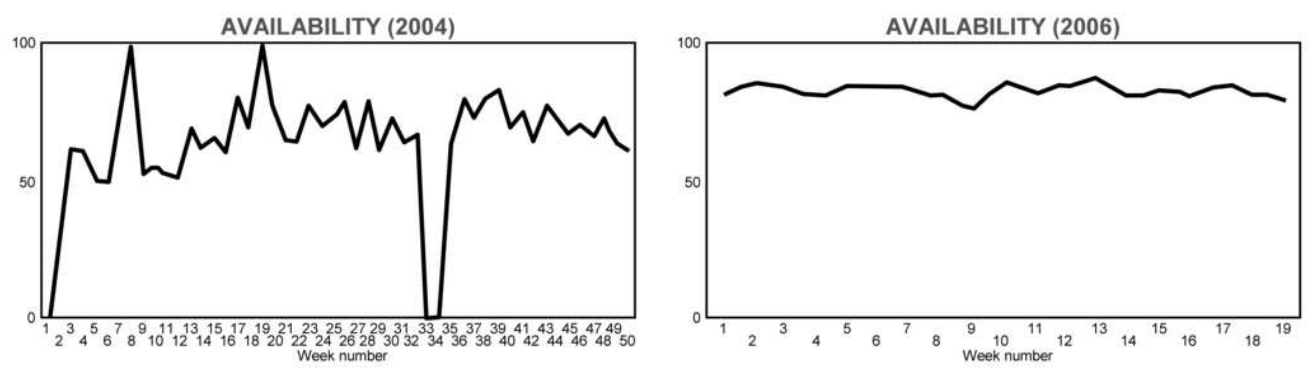

Figure 9. Availability rate improvements from 2004 to 2006 $43 \times 11 \mathrm{~mm}(600 \times 600 \mathrm{DPI})$ 

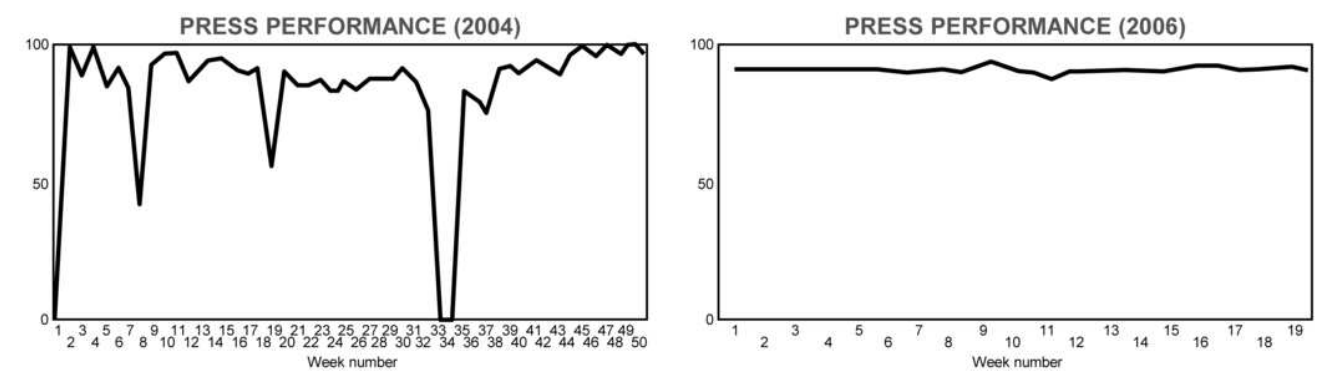

Figure 10. Performance rate improvements from 2004 to 2006 $44 \times 12 \mathrm{~mm}(600 \times 600 \mathrm{DPI})$ 


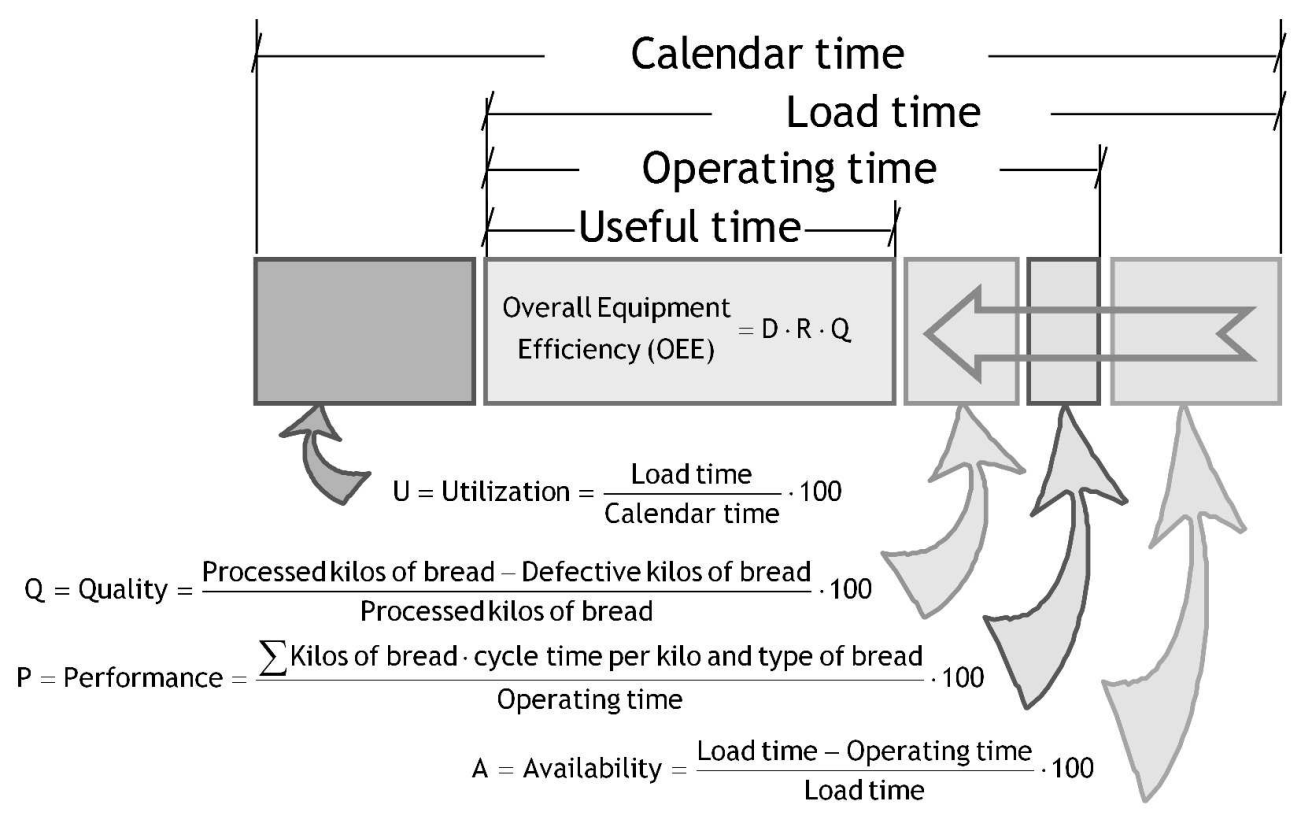

Figure 11. The OEE and the Utilization calculation rates $139 \times 90 \mathrm{~mm}(600 \times 600$ DPI $)$ 

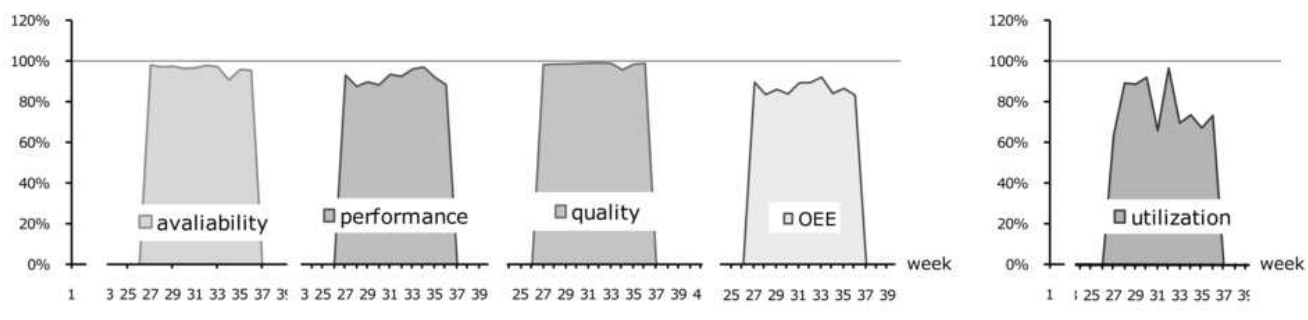

Figure 12. Case study graphical data $39 \times 9 \mathrm{~mm}(600 \times 600 \mathrm{DPI})$ 


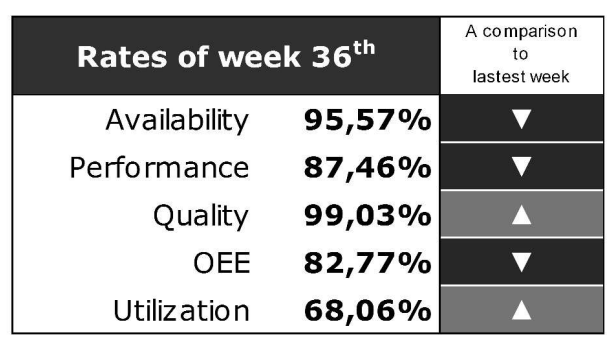

\begin{tabular}{|c|c|c|}
\hline \multicolumn{2}{|c|}{$\begin{array}{l}\text { Cumulative Rates } \\
\text { in the period }\end{array}$} & $\begin{array}{l}\text { A comparison of } \\
\text { week } 3^{\text {th }} \text { and } \\
\text { cumulative rates }\end{array}$ \\
\hline Availability & $96,47 \%$ & $\nabla$ \\
\hline Performance & $90,59 \%$ & $\nabla$ \\
\hline Quality & $98,64 \%$ & $\Delta$ \\
\hline OEE & $86,20 \%$ & $\nabla$ \\
\hline Utilization & $72,38 \%$ & $\nabla$ \\
\hline
\end{tabular}

Figure 13. Case study OEE report $170 \times 41 \mathrm{~mm}(600 \times 600 \mathrm{DPI})$ 

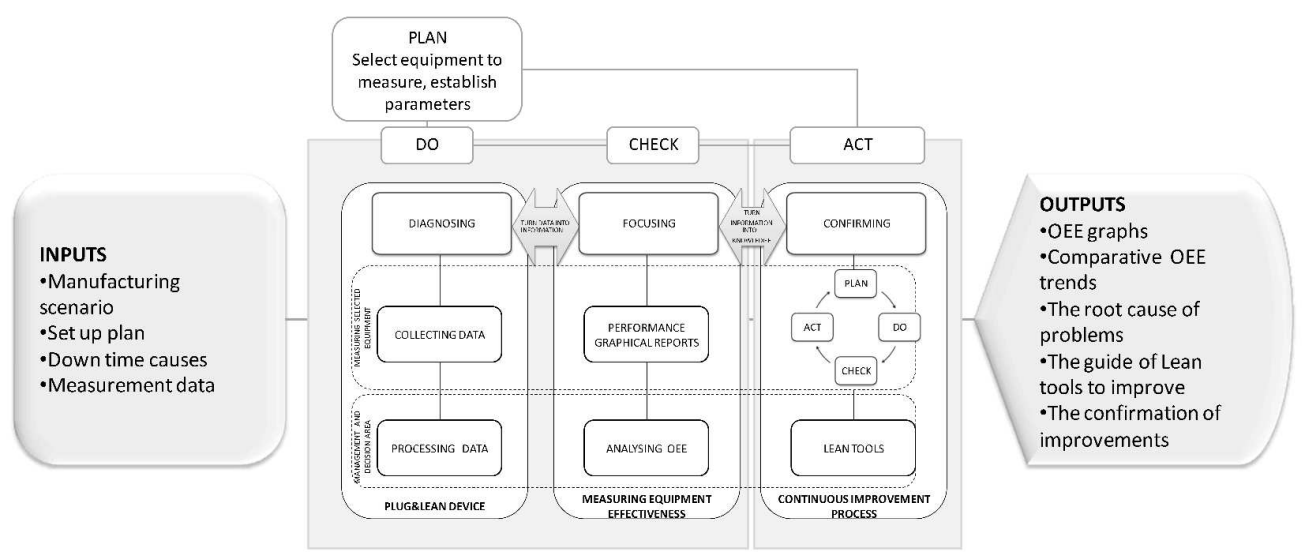

Figure 14. Plug\&Lean framework for continuous improvement $279 \times 120 \mathrm{~mm}(600 \times 600 \mathrm{DPI})$ 


\begin{tabular}{|c|c|c|}
\hline STAGE & TECHNOLOGY & ב CHARACTERISTICS \\
\hline DIAGNOSING & $\begin{array}{l}\text { Wireless Sensors } \\
\text { Wireless Data collector } \\
\text { Network controller } \\
\text { Software control data } \\
\text { Software TPMpro } \\
\text { Scanner barcode equipment } \\
\text { Laptop }\end{array}$ & $\begin{array}{l}\text { ZB counter, ZB timer, ZB therm. } \\
\text { ZB analog 4-20mA, ZB } 4 \text { four entries and ZB report. } \\
\text { ZB CTRL. } \\
\text { ZB Comm. } \\
\text { Infinity-ProFicient suite software (TPMpro Company). } \\
\text { Scanner barcode kit. } \\
\text { Portable Laptop as a PDA. }\end{array}$ \\
\hline FOCUSING ON & $\begin{array}{l}\text { TPM tool kit } \\
\text { Analysis tool kit } \\
\text { Dynamic-down time table }\end{array}$ & $\begin{array}{l}\text { OEE calculation system and Advance graphics tool } \\
\text { (Infinity QS). } \\
\text { Pareto tool and Root cause analysis tool. } \\
\text { Table of down-time codes. }\end{array}$ \\
\hline CONFORMING & Lean quality tools & $\begin{array}{l}\text { Lean manufacturing tools: } \\
\text { TPM process tool, Seven quality tools }\end{array}$ \\
\hline $\begin{array}{l}\text { TECHNOLOGY } \\
\text { NETWORKING }\end{array}$ & $\begin{array}{l}\text { WPAN } \\
\text { Protocol }\end{array}$ & $\begin{array}{l}\text { Wireless personal area networks for communication } \\
\text { between computer and devices. } \\
\text { Routing protocol. }\end{array}$ \\
\hline
\end{tabular}


Table 2 Input data from Line 4

\begin{tabular}{|c|c|c|}
\hline CONCEPT & BEFORE CASE STUDY & AFTER CASE STUDY \\
\hline Calendar time & Not well defined & $\begin{array}{l}\text { It is defined as } 52 \text { weeks } \\
\text { per year, } 5 \text { days a week, } 24 \\
\text { hours per day }\end{array}$ \\
\hline Planned stops & $\begin{array}{l}\text { Calculation based on } \\
\text { maintenance time and } \\
\text { breakdown time }\end{array}$ & $\begin{array}{l}\text { It is defined based only on } \\
\text { time for planned } \\
\text { maintenance }\end{array}$ \\
\hline Operating time & Not well defined & $\begin{array}{l}\text { It is defined as the } \\
\text { calculation of calendar } \\
\text { time minus planned stops }\end{array}$ \\
\hline Cycle time & $\begin{array}{l}\text { Calculation based on } \\
\text { historical data }\end{array}$ & $\begin{array}{l}\text { Calculation based on } \\
\text { theoretical formula }\end{array}$ \\
\hline Total Produced units & $\begin{array}{l}\text { Independent calculation } \\
\text { based only on good quality } \\
\text { units }\end{array}$ & $\begin{array}{l}\text { Calculation based on total } \\
\text { kilos of bread processed }\end{array}$ \\
\hline Defective units & $\begin{array}{l}\text { Independent calculation } \\
\text { based on units rejected due } \\
\text { to quality defects }\end{array}$ & $\begin{array}{l}\text { Calculation based on total } \\
\text { kilos of bread processed } \\
\text { minus total good quality } \\
\text { kilos of bread }\end{array}$ \\
\hline $\begin{array}{l}\text { Defective units to sell as a } \\
\text { second quality level } \\
\text { defective units }\end{array}$ & $\begin{array}{l}\text { Independent calculation } \\
\text { not included in the total of } \\
\text { units processed }\end{array}$ & $\begin{array}{l}\text { Calculation based on } \\
\text { defective kilos of bread } \\
\text { minus rejected kilos of } \\
\text { bread in waste containers }\end{array}$ \\
\hline $\begin{array}{l}\text { Defective units -rejected } \\
\text { non-recovery }\end{array}$ & $\begin{array}{l}\text { Independent and non- } \\
\text { standardized calculation. } \\
\text { Not included in the total } \\
\text { processed units }\end{array}$ & $\begin{array}{l}\text { Calculation based on the } \\
\text { rejected kilos of bread in } \\
\text { waste containers }\end{array}$ \\
\hline OEE rate & Not considered & $\begin{array}{l}\text { Calculation based on the } \\
\text { theoretical formulas }\end{array}$ \\
\hline Production losses & $\begin{array}{l}\text { Independent calculation } \\
\text { taking into account only } \\
\text { the waste in containers }\end{array}$ & $\begin{array}{l}\text { Calculation based on } \\
\text { quality, cost and time } \\
\text { issues. A new } \\
\text { classification of losses. }\end{array}$ \\
\hline $\begin{array}{l}\text { Continuous improvement } \\
\text { methodology }\end{array}$ & $\begin{array}{l}\text { Not defined as a } \\
\text { systematic activity. } \\
\text { Improvement interventions } \\
\text { during corrective } \\
\text { maintenance or a large } \\
\text { quantity of defective units }\end{array}$ & $\begin{array}{l}\text { Defined continuous } \\
\text { improvement } \\
\text { methodology; workers } \\
\text { encouraged to participate } \\
\text { in a interdisciplinary team }\end{array}$ \\
\hline
\end{tabular}


Table 3. Time and quality Production losses after implementing the Plug\&Lean system.

\begin{tabular}{|c|l|}
\hline Ranking & \multicolumn{1}{|c|}{ Production losses } \\
\hline 1 & Non-planned time related to management \\
\hline 2 & Non-planned time related to materials \\
\hline 3 & Set up time \\
\hline 4 & Other losses related to production \\
\hline 5 & Quality losses related to machinery \\
\hline 6 & Quality losses related to personnel \\
\hline 7 & Quality losses related to material \\
\hline 8 & Quality losses related to management \\
\hline
\end{tabular}

